(7)

\title{
Economic Empowerment of Women in Socio-Cultural Perspectives in Federally Administrative Tribal Area (Pakistan): A Case Study of Kurram Agency
}

\author{
${ }^{\text {a }}$ Fazal e Wahid, ${ }^{\mathrm{b}}$ Mehnaz Jaffri, ${ }^{\mathrm{c}}$ Hamid Ullah, ${ }^{\mathrm{d}}$ Muhammad Irshad Khan Mohmand \\ ${ }^{a}$ Assistant Professor, Department of Economics, Islamia College Peshawar, Pakistan \\ Email: Eco_wahid@yahoo.com \\ ${ }^{\mathrm{b}}$ M. Phil. Scholar, Department of Economics, Islamia College Peshawar, Pakistan \\ Email: Jaffri313@gmail.com \\ ${ }^{c}$ Assistant Professor, Department of Management Sciences, Islamia College Peshawar \\ Email: hamidullah@icp.edu.pk \\ ${ }^{\mathrm{d}}$ Ph.D. Scholar, Management Sciences, Quartaba University of Science \& Information Technology, Pakistan \\ Email: irshadmohmand@gmail.com
}

\begin{tabular}{|c|c|}
\hline ARTICLE DETAILS & BSTRACT \\
\hline $\begin{array}{l}\text { History: } \\
\text { Accepted: } 11 \text { May } 2020 \\
\text { Available Online: } 15 \text { June } 2020\end{array}$ & $\begin{array}{l}\text { The study investigates the indicators that effect women's economic } \\
\text { empowerment. The data collected through questionnaires, with } 350 \text { sample } \\
\text { dimension. Pragmatic results expose that enrolment of female in education, } \\
\text { decision making power, decision concerning household asset and economic }\end{array}$ \\
\hline $\begin{array}{l}\text { Keywords: } \\
\text { Economic Empowerment of } \\
\text { Women, Enrolment of Female in } \\
\text { Education, Decision Making } \\
\text { Power, Decision Concerning } \\
\text { Household Asset, Economic } \\
\text { Opportunities, Socio-Cultural } \\
\text { Issues, Gender Partialities, } \\
\text { Poverty And Male Dominancy }\end{array}$ & $\begin{array}{l}\text { opportunities have positive effected on WEE and significant. Participation in } \\
\text { economy \& educational retrieve hold positive and insignificant effect on WEE } \\
\text { due to limited access to educationalists, masculinity basis, male dominancy } \\
\text { etc. Problems of socio-cultural, poverty have negative and insignificant effect } \\
\text { on WEE because of cultural restrictions; female workers are bounded to } \\
\text { teaching field \& functioning in their own lands. Finally, the recommendations } \\
\text { of the study are that free access should be given to women for education } \\
\text { regardless of ethnicity, sexual partialities and may be allowed to work along } \\
\text { their male equivalents in order to raise the level of economic empowerment } \\
\text { of women. The same will subsequently enhance their potential for }\end{array}$ \\
\hline $\begin{array}{l}\text { JEL } \\
M 5 \\
\end{array}$ & \\
\hline DOI & $\begin{array}{l}\text { (C) } 2020 \text { The authors. Published by SPCRD Global Publishing. This is an open } \\
\text { access article under the Creative Commons Attribution-NonCommercial } 4.0\end{array}$ \\
\hline
\end{tabular}

Corresponding author's email address: Eco_wahid@yahoo.com

\section{Introduction}

In social, economic, and political views, empowerment has a huge deal of varieties. Generally, it is used to trace association indoors families between orphaned clusters and other societies globally (Miraj, 2k16). Women's empowerment as a state in which females dominate equivalent rights of household strength, educational facilities, and political rights. Empowerment of women have basic center of magnetism and antedate huge entrée to information, economic facilities and decision making according to economy and politics (Kabir, 2005). The main determinant for empowerment is education 
Review of Economics and Development Studies, Vol. 6 (2) 2020, 257-266

which is dynamic for improvement of human awareness, giving equal opportunities and status to achieve their objectives and anticipated aims (Bushra, 2k13). Education make women empower more effectively which would eradicate sexual difference, increase social and economic returns, advance their potentials, change their life style, produce healthy and educated children, shrink fertility and mortality rate, increase participation of women in labour market which decrease the deficiency of resources. Education is the key to participation of females in decision, active revolution and significant vocation of upcoming generation. Institutional expansion and socialization of women show important role in women economic participation and their decision making. Poverty is the factor that avoid women from education, consuming nutrition foods, retrieving multiplicative healthcare facilities. Decreasing gender inequality and encouraging women education are amid the crucial approaches to reduce material and infant mortality (Abase, 2k15). If female is educated, take rational decision and well knowledgeable, then empowerment would become supplementary significant.

The basic feature of women progress is women economic empowerment which can lead female to several economic resources and springs mental relaxation from being poor women. It makes free from condition like food crises, scarcity, accidents in the household and deaths etc. Economic empowerment increases the participation of females in labour market, reduces poverty and increases production in all segments. When women are empowered then they can support their family \& can preserve their living standard through access of education and other basic needs (Sohail, 2k14).

The reasons behind disempowerment of women are deficiency of control of productive resources, insufficient access to institutional causes of credit due to lack of ability to provide security, sexual discrimination, male dominancy and deficiency of skills which affects the right of females in economic participation and political activities. In general, lack of public responsiveness, inadequate control over family earnings and elimination in family's decision, education of girls \& sale or purchase of assets. In the study area, the reason behind disempowerment is male dominancy and socio-cultural issues i.e religious system, civilization and the most challenged is that women cannot share their feelings and wishes to express themselves.

\section{Literature Review}

There are numerous studies which discussed women empowerment but only few examine the true concept of women empowerment. The pragmatic research showed that women education, participation of women in economic, social justice, economic opportunities, gender inequality, women having bank account and labour force participation increases empowerment of women.

Noreen and Khalid (2k12) discussed women empowerment by explaining the effect of women education, decision of parents and women having any assets or property. The main factor for women's empowerment is female education but early age marriage and poverty are the factors which reduces girl's education. Sandhys (2k15) also discussed women empowerment by female's education with special focus on rural areas according their decision and women's empowerment.

Meraj (2k16) discussed women empowerment by focusing political and socio-economic factors of women empowerment. The report presented female's age, schooling's level, status of working, monthly income, resources to economic credit, female bank account, educational and health resources, investment in different saving organizations, residence's area and positive and statistically significant.

Bushra (2k15) studied factors on women empowerment. The study found the content of women's education, women's participation in economic, economic opportunities, poverty \& women 
Review of Economics and Development Studies, Vol. 6 (2) 2020, 257-266

having personal bank account increases women's empowerment. Awan and Iqbal (2k15) studied that empowerment of women means self-dependent, freedom and their resources to opportunities. Women's empowerment is improving their situation in authority structure of the society.

Butt (2k14) discussed females at indigenous frames' level and women's role in indigenous representation. Indigenous representation is one of the valuable instruments to empower women. In Pakistan, females are empowered but they are not empowered in actual standings. Females at common level are usually blocked, consequent and seen minimum concerned about their rights, role in political affairs. For real women's empowerment, resident illustration should be reinforced by expressive contribution and greater percentage of women. This stage can be used as a nursery to train them for rational level of politics and to have their due rights.

Akinsanya (2k11) create that females are followers in the growth of economy, but there are some determinants which disturb the contribution of women in economy. The report presented that women's education conveying empowerment to females which can face challenges that are encountered in working \& realizing other societal roles and occasions.

\section{Methodological Framework}

There are several approaches to women empowerment, but no one equally select categories, however only express the reasons of disempowerment of females. All these approaches are conscious raising approach, integrated approach, economic empowerment approach which discussed Batlewala (1985). Increasing women's educational institutions and having universal acceptance of female's education frequently indicate to growth of economics, which absolutely affected on women's contribution in all level of professional \& reducing household's responsibility and family strength. This theory was presented by Heckman et al. 1980 and theory says that innovation procedure demand on behalf of labour which providing superior chances in all fields for women.

Lewis theory of surplus labour in 1954 says that rapidly transferring of labour from agricultural sectors to manufacturing sectors indicate to obtain survival earnings, revenue of modern sectors exceeds \& additional produces economic growth. The overall process of moving of labour and modern sectors economic growth leads to generate the development of country's economy. Mostly females are working in agricultural sectors, uncertainty they will be authorizing then they transfer to other sectors and rate of female workers will be increase. The transferring of women from agricultural sectors to further divisions will not affect the efficiency of agricultural sectors but will increase the productivity of all other sectors where organize females from agricultural sectors (Todaro and Smith 2009).

\subsection{Model}

$$
\begin{gathered}
W E E=f(A, A g, E A, M E, F E S, S C I, D M P, P, D R F S, E O, E P) \\
W E E=\beta 0+\beta 1 A+\beta 2 A g+\beta 3 E A+\beta 4 M E+\beta 5 F E S+\beta 6 S C I+\beta 7 D M P+\beta 8 P+\beta 9 D R F S \\
+\beta 10 E O+\beta 11 E P+\varepsilon
\end{gathered}
$$

WEE $=$ Women economic empowerment

$\mathrm{A}=$ Area (control variables)

$\mathrm{Ag}=$ Age (control variables)

$\mathrm{EA}=$ Educational access (control variables)

$\mathrm{ME}=$ Mother's education (control variables)

$\mathrm{FES}=$ Female enrolment in schools

$\mathrm{SCi}$ - Socio-cultural issues

$\mathrm{DMP}=$ Decision making power 
$\mathrm{P}=$ poverty

DRFS $=$ Decision regarding family strength

$\mathrm{EO}=$ economic opportunities

$\mathrm{EP}=$ Economic participation

$\beta_{\mathrm{o}}$ is the intercept and $\beta_{1}, \beta_{2}, \beta_{3}, \beta_{4}, \beta_{5}, \beta_{6}, \beta_{7}, \beta_{8}, \beta_{9}, \beta_{10}$, and $\beta_{11}$ representing slopes of regression equation and $\varepsilon$ is error term.

\subsection{Data Sources:}

Primary data has been collected through random cluster sampling. The sample size is 350 which has been selected based on educational \& population level. The data has been composed through questionnaires by interview schedule, females of the age 20-45 have been interviewed. All married/unmarried, working/non-working, educated/uneducated females have been included which compare their values of empowerment index in Kurram Agency.

\subsection{Econometric Models}

Data examined through different statistical methods. Main variables in this study have contain sub variables due to the lack of robust data available at district level for a number of indicators which are significant to evaluate economic empowerment of women. Selected the sub-variables of each main variable and then find independently. Different tests have applied on data which is correlation, histogram, q-q plot, multi-collinearity, Durban-Watson, heteroscedasticity and then used Linear Regression analysis on different variables on economic empowerment of women in Kurram Agency.

\section{Empirical Results}

Results of Linear Regression Analysis in table showed that some variables have significant impact on women economic empowerment. The analysis showed that educational access, FES \& ME have positive effect on economic empowerment of women according to economic theory. Coefficient of EA showed that 1 unit increase in EA has improved women economic empowerment by 0.034 units and statistically insignificant because limited EA are irrespective of ethnicity, sexual biases etc. in the research zone. The coefficient of mother education showed that 1 unit increase in ME has increased women economic empowerment by 0.037 units but statistically insignificant due to male dominancy in the study area. Coefficient of FES showed that 1 unit increase in FES has increased women economic empowerment by 0.13 units and statistically significant. SCI negatively have effects on women economic empowerment which showed inverse connection among them and significant at 5\%. Its coefficient showed that 1 unit increase in SCI have reduced women economic empowerment by 0.169 units. It showed that the research area will be as deeply rigid. DMP has positively effects on women economic empowerment and significant at 5\%. Coefficient of decision making showed 1 unit increase in DMP will get 0.119 units increase women economic empowerment. Poverty has negative effect on women economic empowerment and its coefficient showed that 1 unit increase in $\mathrm{P}$ has reduced economic empowerment of women by 0.73 which is according to economic theory but insignificant because poor families have financial limitations which results in reduction of female's education, other basic requirements. DRFS has positive effects on women economic empowerment \& statistically significant. Coefficient of DRFS showed that 1 unit increase in decision has improved women economic empowerment by 0.136 units. Economic opportunities have positive effects on WEE and statistically significant. Coefficient of EO showed that 1 unit increase in opportunity has increased women economic empowerment by 0.11 units. EP has positive effects on women economic empowerment and statistically insignificant due to limited access to education regardless of ethnicity, sexual biases etc. Coefficient of EP showed that 1 unit increase in EP has increased women economic empowerment by 0.012 units. 
Review of Economics and Development Studies, Vol. 6 (2) 2020, 257-266

$\mathrm{R}^{2}$ is 0.414 showed that $41 \%$ of variation in women economic empowerment is due to descriptive variables. F-statistic showed that model is significant at $5 \%$ level. Value of Durban-Watson test 1.610 which showed that there is no series autocorrelation issues.

Table 4.1: Results of Linear Regression

\begin{tabular}{|c|c|c|c|c|c|}
\hline \multirow{2}{*}{$\begin{array}{c}\text { MODEL } \\
\text { I }\end{array}$} & \multicolumn{2}{|c|}{$\begin{array}{c}\text { Unstandardized } \\
\text { Coefficients }\end{array}$} & $\begin{array}{c}\text { Standardize } \\
\mathrm{d} \\
\text { Coefficients }\end{array}$ & \multirow{2}{*}{ Sig. } \\
\cline { 2 - 5 } & $\beta$ & Std. Error & $\beta$ & & \\
\hline Const & 2.328 & .421 & & 5.534 & .000 \\
\hline A & -.100 & .051 & -.093 & -1.970 & .050 \\
\hline Ag & -.061 & .027 & -.100 & -2.258 & .025 \\
\hline ME & .034 & .049 & .042 & .690 & .491 \\
\hline FES & .037 & .033 & .053 & 1.124 & .262 \\
\hline SCI & .130 & .042 & .199 & 3.085 & .002 \\
\hline DMP & -.169 & .045 & -.167 & -3.728 & .000 \\
\hline P & .119 & .050 & .135 & 2.390 & .017 \\
\hline DRFS & -.073 & .048 & -.078 & -1.518 & .130 \\
\hline EO & .136 & .035 & .179 & 3.890 & .000 \\
\hline EP & .110 & .042 & .153 & 2.646 & .009 \\
\hline$R^{2}=0.433$ & .012 & .043 & .014 & .286 & .775 \\
\hline $\begin{array}{c}\text { Adjusted R }{ }^{2}=0.414 \\
\text { F-Statistics = 23.442 }\end{array}$ & & & & & \\
\hline $\begin{array}{c}\text { Pro(F-stat) }=0.000 \\
\text { Durbin-Watson =1.610 }\end{array}$ & & & & & \\
\hline
\end{tabular}

\subsection{Correlation}

Correlation test has used to check the correlation among the dependent and independent variables of primary data. The result of correlation test showed that FES, SCI, P, DMP, EO and EP have highly correlated with women economic empowerment.

Table 4.2: Correlation Test

\begin{tabular}{|c||l|l|l|l|l|l|l|l|}
\hline & \multicolumn{1}{c|}{ WEE } & \multicolumn{1}{c|}{ FES } & \multicolumn{1}{c|}{ SCI } & DMP & \multicolumn{1}{c|}{ P } & \multicolumn{1}{c|}{ DRFS } & EO & \multicolumn{1}{c|}{ EP } \\
\hline WEE & 1 & $.461^{* *}$ & $-.330^{* *}$ & $.482^{* *}$ & $-.370^{* *}$ & $.387^{* *}$ & $.501^{* *}$ & $.349^{* *}$ \\
\hline FES & $.461^{* *}$ & 1 & $-.242^{* *}$ & $.420^{* *}$ & $-.382^{* *}$ & $.228^{* *}$ & $.500^{* *}$ & $.392^{* *}$ \\
\hline SCI & $-.330^{* *}$ & $-.242^{* *}$ & 1 & $-.289^{* *}$ & $.206^{* *}$ & $-.130^{*}$ & $-.291^{* *}$ & $-.200^{* *}$ \\
\hline DMP & $.482^{* *}$ & $.420^{* *}$ & $-.289^{* *}$ & 1 & $-.433^{* *}$ & $.324^{* *}$ & $.562^{* *}$ & $.360^{* *}$ \\
\hline P & $-.370^{* *}$ & $-.382^{* *}$ & $.206^{* *}$ & $-.433^{* *}$ & 1 & $-.310^{* *}$ & $-.452^{* *}$ & $-.449^{* *}$ \\
\hline DRFS & $.387^{* *}$ & $.228^{* *}$ & $-.130^{*}$ & $.324^{* *}$ & $-.310^{* *}$ & 1 & $.300^{* *}$ & $.350^{* *}$ \\
\hline EO & $.501^{* *}$ & $.500^{* *}$ & $-.291^{* *}$ & $.562^{* *}$ & $-.452^{* *}$ & $.300^{* *}$ & 1 & $.451^{* *}$ \\
\hline EP & $.349^{* *}$ & $.392^{* *}$ & $-.200^{* *}$ & $.360^{* *}$ & $-.449^{* *}$ & $.350^{* *}$ & $.451^{* *}$ & 1 \\
\hline
\end{tabular}

\subsection{Normal Q-Q Plot}

This test has been used to check the normality of descriptive variables. When dots of data are near to diagonal line its mean data are normally distributed but when points are away to diagonal it means 
data are not normally distributed. In this graph, mostly dots are near to diagonal line it means present data are normally distributed.

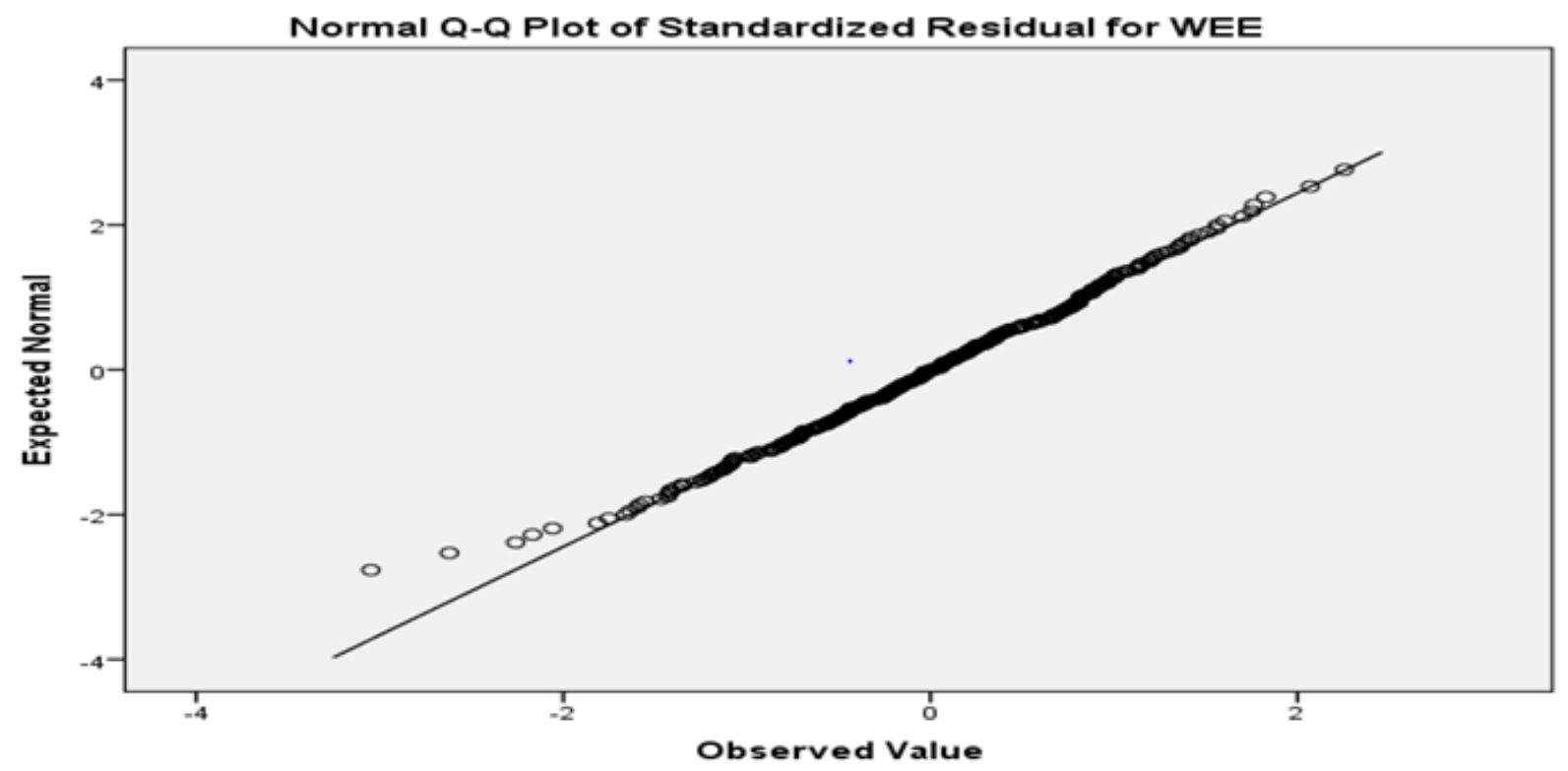

\subsection{Histogram}

Histogram also used to check the normality of data but here we check the standard deviation value, because there is no value of $\mathrm{P}$ in primary data. In this graph the standard deviation value is 0.984 which is greater than $5 \%$. When the value of standard deviation is greater than $5 \%$ its mean that we cannot reject our null hypothesis that residuals are in a normal distribution. This graph also showed normal distribution its mean we accept our null hypothesis.

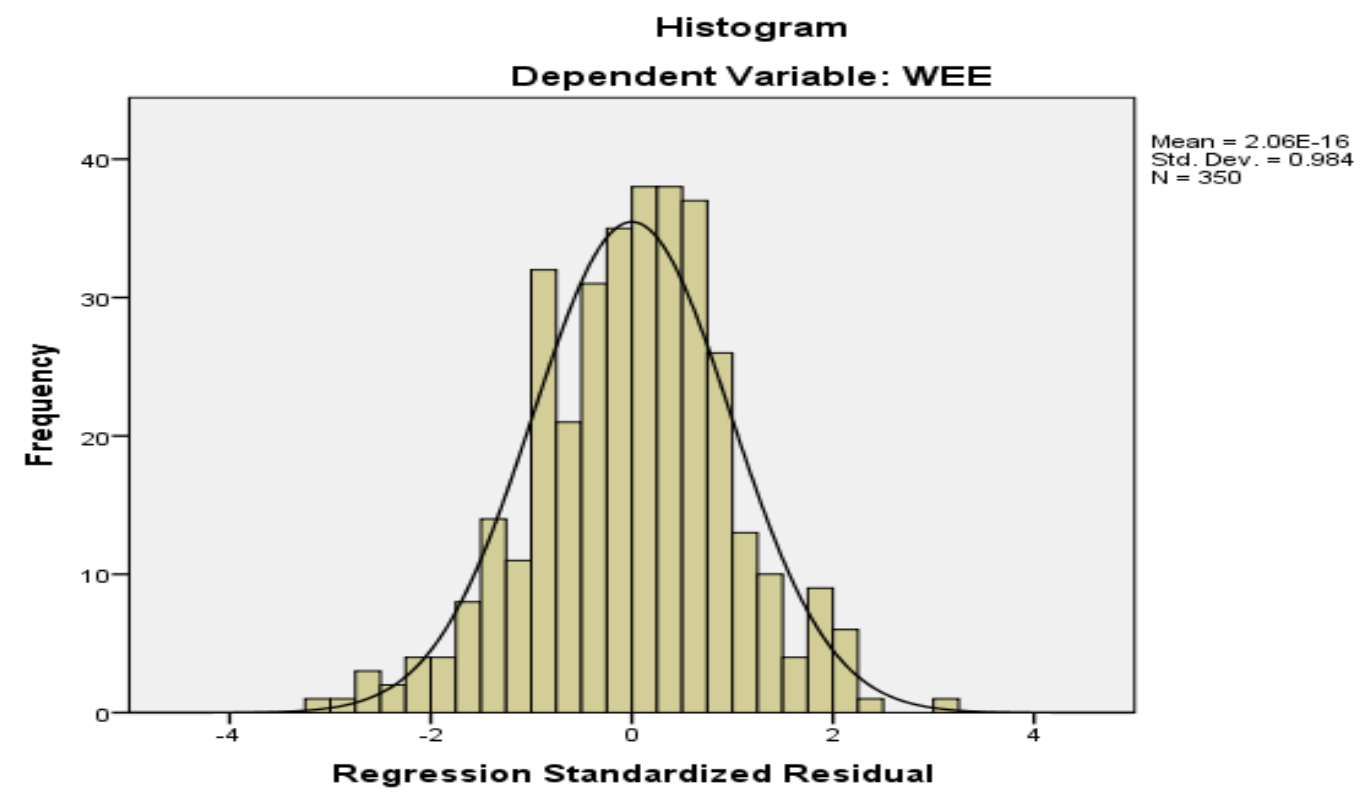

4.4 Linearity

In this test we check the linearity of model. In the below graph, the blank boxes showed the 
linear relationship between economic empowerment of women and FES, SCI, P, DMP, EO. EP.

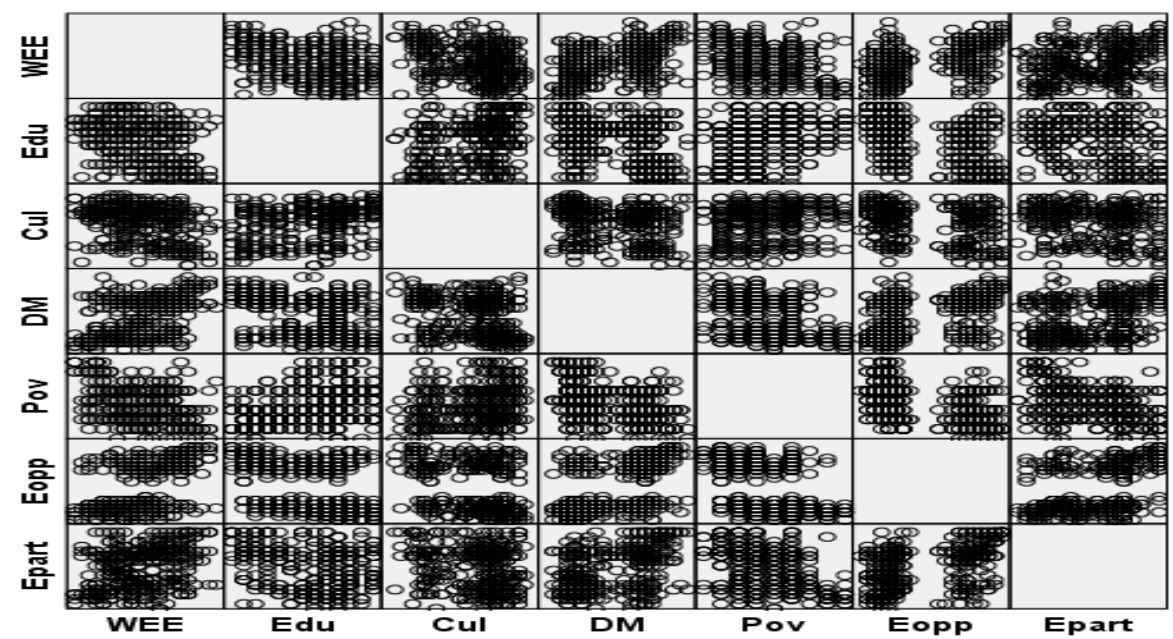

\subsection{Durban-Watson Test}

In table 4.3 , value of Durban-Watson test is 1.610 which is approximately equal to 2 , it means that there is no autocorrelation.

Table 4.3: Durban-Watson Test

\begin{tabular}{|l|l|l|l|l|l|}
\hline MODEL & $\mathrm{R}$ & $\mathrm{R}^{2}$ & Adjusted $\mathrm{R}^{2}$ & $\begin{array}{l}\text { Std. Error of } \\
\text { the Estimate }\end{array}$ & $\begin{array}{l}\text { Durbin- } \\
\text { Watson }\end{array}$ \\
\hline $\mathrm{I}$ & 0.658 & 0.433 & 0.414 & 0.69867 & 1.610 \\
\hline
\end{tabular}

\subsection{Multi-Collinearity}

The variance inflation factor has been used for finding the multi-collinearity problems. If the value of VIF is greater than 5 its mean there is multi=-collinearity problems between explanatory variables, but if its value is less than 5 means there is no multi-collinearity problem. In table 4.4 , the value of VIF of each variable is less than 5 , showed that there is no multi-collinearity among explanatory variables.

Table 4.4: VIF

\begin{tabular}{|l|l|l|l|l|l|l|l|l|l|l|}
\hline $\mathrm{Ar}$ & $\mathrm{Ag}$ & EA & ME & FES & SCI & DMP & P & DRFS & EO & EP \\
\hline & & & & & & & & & & \\
1.340 & 1.162 & 2.245 & 1.335 & 2.467 & 1.202 & 1.903 & 1.578 & 1.256 & 1.990 & 1.520 \\
\hline
\end{tabular}

\subsection{Heteroscedasticity}

In Regression Model, the residuals have a constant variance. To check the residuals we used heteroscedasdicity. In below graph, random scattered points are all around zero. Vertical width is being constant throughout values showed that the residuals have a constant variance. 


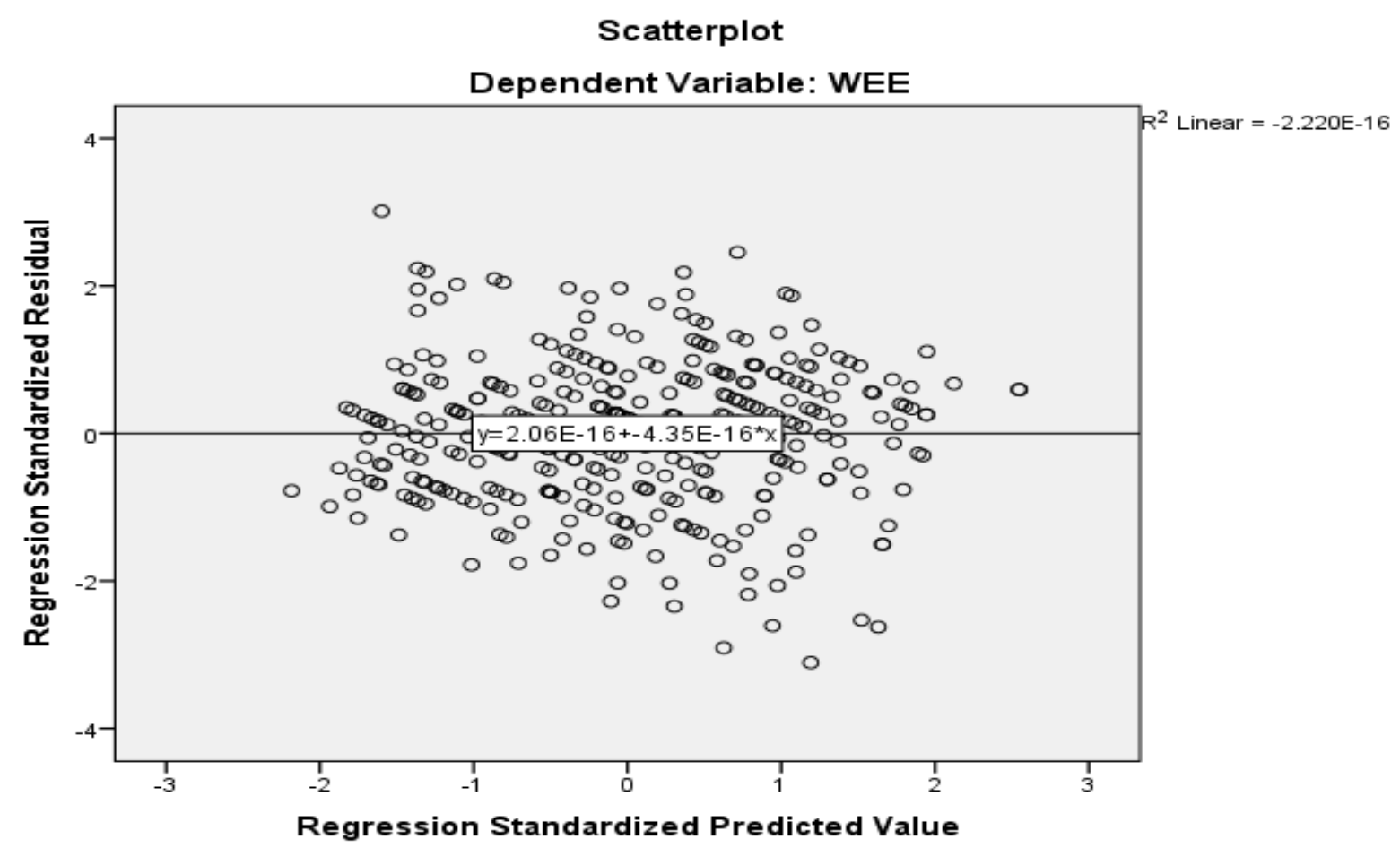

\subsection{Residuals}

Residual has zero means is also the assumption of Regression Model. In table 4.5, the mean of the residual is equal to zero, so it satisfied the assumption of linear regression model.

Table 4.5: Residuals Statistic

\begin{tabular}{|l|l|l|l|l|l|}
\hline & Min & Max & Mean & Std. Dev & N \\
\hline Predicted Value & 1.5427 & 4.3860 & 2.8549 & .60056 & 350 \\
\hline Residual & -2.17074 & 2.10512 & .00000 & .68758 & 350 \\
\hline Std. P-V & -2.185 & 2.549 & .000 & 1.000 & 350 \\
\hline Std. Residual & -3.107 & 3.013 & .000 & .984 & 350 \\
\hline
\end{tabular}

\section{Conclusion}

Women empowerment is totally dependent on female's education. Other determinants like economic opportunities, economic participation, decision making power have major contribution to empowerment of women. But SCI and P have adversely affected on empowerment of women. The study concluded that educated women can take their decision regarding career, marriage, number of children health care etc., it means that educated females are more empowered as compared to uneducated women. The analysis concluded that females have very less decision power in the study zone. Economic empowerment improves with increase in freedom to decision regarding their career, family strength, marriage etc. In the study area, the main reason of disempowerment of women are socio-cultural issues.

\section{Recommendation}


Review of Economics and Development Studies, Vol. 6 (2) 2020, 257-266

- Education is the right of women and it is very important for women's empowerment. Equal opportunities could be provided to females of FATA. Public strategies with respect to females education as well as technical education may be applied and increased number of seats for women in other educational institutions outside FATA and same standard of institutions may be made available in the study area.

- Mother's education has direct bearing on economic empowerment of women, which can subsequently educate their children and can participate in economic growth of the family as well.

- Society should implement strategies for conductive working environment of females. Should be encourage to work along their male counterparts in every field of life.

- All women specially educated females should be accessed taken into confidence in any decision regarding their career, marriage, family planning etc. therefore women should be made part of all decision making process.

- In the study area, government should open girls schools in every village, so as even poor family may easily send their children to school. Thereby when girls get education then they will be able to take decision about their career and can achieve economic self-confidence and can take part in uplifting the economic statues of their family.

\section{References}

Awan, A.G. \& Iqbal, (2015). Role of Microfinance in Poverty Alleviation: Evidence from Pakistan. American Journal of Trade and Policy, Vol 2, (1) p. 37-44.

Batliwala, S., (1985). Women in poverty: The Energy, Health and Nutrition Syndrome. In Jain, D. and Banerjee, N. (eds), Tryanny of the Household: Investigative Essays on Women's work, New Dehli, India: Shakti books.

Bushra, A, \& Wajiha, N, (2013). Assessing the Determinants of Women Empowerment in Pakistan. Pakistan Journal of Applied Economics, Vol23, (2), p. 115-139.

Bushra, A., \&Wajiha, N, (2015). Assessing the Socio-economic Determinants of Women Empowerment in Pakistan. Procedia-Social and Behavioral Sciences, Vol177, p. 3-8.

Bera, N, (2016). Women Empowerment through Education. International Journal of Humanities \& Social Science Studies. Vol-II, Issue-VI, p. 184-19o.

Heckman, James, (1980). Female Labor Supply Theory and Estimation. Princeton. Princeton University Press, Vol 57 (1), p. 32-53.

JehanQamar, (2000). Role of Women in Economic Development of Pakistan. University of Balochistan Quetta.

Krausz, S. L, (1986). Sex role within marriage. Social work, Vol 31 (6), p. 457-464.

Kishor, S, (1997). Empowerment of women in Egypt and links to the survival health of their infants. International Union for the Scientific Study of Population, Oxford University Press.

Kabeer\&Naila, (2005). Gender Equality and Women's Empowerment. A Critical Analysis of the Third Millennium Development Goal. Gender and Development, Vol13 (1) p. 13-24.

Khan, A, (2007). Women and paid work in Pakistan: Pathways of women's empowerment. Scoping article for the South Asia Research Programme. Karachi: Collective for Social Science Background Paper Prepared for the World Bank Workshop Poverty and Gender: New Perspectives. Research, Vol 26 (3), p. 127-131.

Khan, N. A, (2012). Socio-Economic and Political Status of Women in FATA-The Process of Development and Phenomenon of Militancy. TIGAH. A Journal of Peace and Development, Vol2, p. 1-21.

Malhorta et al, (2002). Measuring Women's Empowerment as a Variable in International Development.

Meraj, M., \&Sadaqat, M. B. (2016). Gender equality and socio-economic development through women's empowerment in Pakistan. Vol 34, p. 143-153. 
Rafay, B. Habib, B, \& Tariq, U, (2016). Analysis on the Social Legislation and Women Empowerment in Pakistan: Comparative study of Democratic governments and Dictatorship periods (1947-2012). JRSP, Vol. 53 (1), p. 23.

Standing, Guy, (1981). Labour Force Participation and Development, Geneva: International Labour Office. Vol 19 (4), p. 514-516.

Sathar, Z. A \& S. Kazi, (2000). Women's autonomy in the context of rural Pakistan. The Pakistan Development Review, Vol 39, (2), p. 89-110.

Suguna, B, (2006). Empowerment of Rural Women through Self Help Groups. Discovery Publishing House, New Delhi, Vol 1 (1). P. 35 - 45.

Sethuraman, K, (2008). The role of women's empowerment and domestic violence in child growth and under nutrition in a tribal and rural community in south India (No. 2008/15). Research Paper, UNU-WIDER, United Nations University (UNU).

Todaro, M., \& Smith, S, (2009). Economic development (10th ed.). Boston: Addison Wesley.

UNDP (1996). Human Development Report. New York: United Nations Development Programme. 